\title{
Concentrations of endothelial-cell-stimulating angiogenesis factor, a major component of human uterine angiogenesis factor, in human and bovine embryonic tissues and decidua
}

\author{
C. M. Taylor ${ }^{1}$, B. McLaughlin ${ }^{1}$, J. B. Weiss ${ }^{1}$ and N. G. Maroudas ${ }^{2}$ \\ ${ }^{1}$ Wolfson Angiogenesis Unit, Department of Rheumatology, Hope Hospital, Salford M6 8HD, UK; \\ and ${ }^{2}$ Department of Microbiology, University of Surrey, Guildford, Surrey GU2 $5 X H, U K$
}

\begin{abstract}
Summary. Embryonic development involves the establishment of new patterns of vascular growth in the fetus and within the lining of the womb. A factor, human uterine angiogenesis factor, has been purified from the decidua and stimulates the growth of blood vessels in collagen sponge implants and in the chick chorioallantoic membrane. Evidence is presented that suggests that a major active component of human uterine angiogenesis factor is an activator of latent matrix metalloproteinases, of low $M_{\mathrm{r}}$, called endothelial-cell-stimulating angiogenesis factor and that this factor is present in substantial quantities in a number of embryonic tissues.
\end{abstract}

Kelwords: angiogenesis; growth factor; collagenase; endothelial-cell-stimulating angiogenesis factor; human uterine angiogenesis factor

\section{Introduction}

Embryological development involves the establishment of two new networks of blood vessels, one produced by the embryo itself and one arising within the lining of the womb (decidua) in response to the growing demands of the developing fetus. Growth factors are known to play a critical role in the control of embryological development (Mercola \& Stiles, 1988) and the presence of angiogenic activity in fetal tissues has been demonstrated (Burgos, 1983; Gospodarowicz et al., 1985) and ascribed to fibroblast growth factors. Human uterine angiogenesis factor (HUAF), an extract derived from decidua obtained from first trimester legal terminations of pregnancy, induced neovascularization of the chorioallantoic membrane (Maroudas et al., 1987) and vascularization of collagen sponge implants (Lindenbaum et al., 1989). The active components of this extract are known to be of $M_{\mathrm{r}} 30000$ or less and one has been identified as fibroblast growth factor (FGF) (Lindenbaum et al., 1989).

Endothelial-cell-stimulating angiogenesis factor (ESAF) is a nonprotein, microvessel, cellspecific mitogen of low $M_{\mathrm{r}}$, which is capable of activating latent matrix metalloproteinases by dissociating the complexes formed with tissue inhibitor of metalloproteinases (TIMP) and also of activating promatrix metalloproteinases (McLaughlin et al., 1991). This factor occurs in high concentrations where angiogenesis is occurring, such as in conditions of proliferative retinopathy (Taylor et al., 1986, 1989) or in the epiphyseal growth plate (Brown et al., 1987). Significant synergism exists between ESAF and FGF in the stimulation of cultured microvessel endothelial cells (Odedra \& Weiss, 1987) and tissues rich in FGFs tend to contain high concentrations of ESAF (Taylor et al., 1988). In this study we demonstrated that ESAF, like FGF, can be extracted from fetal tissues and decidua and is a constituent of HUAF. 


\section{Materials and Methods}

\section{Extraction of ESAF from decidual and fetal tissues}

Decidual tissue was obtained from human pregnancies legally terminated during the first trimester and the material was pooled. Fetal bovine tissues were obtained from the local abattoir, gestational age being determined by the method of Bogart (1959). Lyophilized decidua were homogenized for $15 \mathrm{~s}$ at $4^{\circ} \mathrm{C}$ in $\mathrm{NH}_{4} \mathrm{HCO}_{3}$ buffer $(20 \mathrm{ml}$, $50 \mathrm{mmol} / 1, \mathrm{pH} 7.9)$ containing $2 \mathrm{~mol} \mathrm{MgCl}_{2} / 1$ to remove bound ESAF from its carrier protein. Samples were centrifuged at $20000 \mathrm{~g}\left(1 \mathrm{~h}, 4^{\circ} \mathrm{C}\right.$ ). The supernatants were assayed for protein (Lowry et al., 1951) prior to diafiltration on a YM5 filter membrane ( $M_{\mathrm{r}} 5000$ exclusion limit; Amicon Ltd, Stonehouse, Glos, UK) with three volumes of bicarbonate buffer. The diafiltrates containing the ESAF were reduced by rotary evaporation to a volume of $10 \mathrm{ml}$ and applied to an octodecyl silica column (Analytichem, Harbor City, CA, USA). Bound angiogenic material of low $M_{\mathrm{r}}$ was eluted with stepped gradient methanol and assayed. One sample from mixed supernatants was put through the complex purification procedure using high pressure liquid chromatography (HPLC) and the position of the active peak was compared with other known preparations of ESAF.

\section{Extraction of HUAF from decidua}

After homogenization of pooled human decidua in water, precipitation with $3 \%$ glacial acetic acid and rapid neutralization with $\mathrm{NH}_{4} \mathrm{OH}$, the crude extract was centrifuged and the supernatant filtered through a membrane cartridge $\left(M_{\mathrm{r}} 30000\right.$ exclusion limit; Millipore Ltd, London, UK). The filtrate was then reduced to $10 \mathrm{ml}$ by rotary evaporation and stored at $-20^{\circ} \mathrm{C}$.

\section{Extraction of ESAF from HUAF}

The $10 \mathrm{ml}$ fraction of HUAF was diluted with an equal volume of $\mathrm{NH}_{4} \mathrm{HCO}_{3}$ buffer $(20 \mathrm{ml}, 50 \mathrm{mmol} / \mathrm{l}, \mathrm{pH} 7.9)$ containing $2 \mathrm{~mol} \mathrm{MgCl}_{2} / 1$ to dissociate bound ESAF and diafiltered on a YM5 membrane with three volumes of bicarbonate buffer. The diafiltrate was reduced to $10 \mathrm{ml}$ by rotary evaporation and the ESAF was isolated as described. The protein content of the HUAF fraction was determined prior to diafiltration.

\section{Assay of ESAF using activation of latent collagenase}

Samples were assayed for their ability to activate latent collagenase according to the method of Weiss et al. (1983). Briefly, $75 \mu \mathrm{l}$ of the test extract with $25 \mu \mathrm{l}$ procollagenase was added to $50 \mu \mathrm{g}$ collagen substrate, in $25 \mu \mathrm{l}$ of $0.05 \mathrm{~mol}$ Tris$\mathrm{HCl}$ buffer $/ \mathrm{l}$ at $\mathrm{pH} 7 \cdot 6$, containing $0.2 \mathrm{~mol} \mathrm{NaCl} / 1$ and $0.01 \mathrm{~mol} \mathrm{CaCl} / 1$, which had been allowed to gel at $37^{\circ} \mathrm{C}$ for $30 \mathrm{~min}$. The volume in the assay tube was made up to $300 \mu$ and the tubes were incubated at $35^{\circ} \mathrm{C}$ for $4 \mathrm{~h}$. At this time, $150 \mu \mathrm{NaCl}$ $(6 \mathrm{~mol} / \mathrm{l})$ was added to precipitate any undigested, but solubilized, collagen and the tubes were allowed to stand at room temperature for $30 \mathrm{~min}$ before centrifugation at $1700 \mathrm{~g}$ for $30 \mathrm{~min}$. Then, $200 \mu \mathrm{l}$ of supernatant was added to $5 \mathrm{ml}$ scintillation cocktail and the radioactivity was measured (in c.p.m.). Clostridiopeptidase was used to determine the total radioactivity in $50 \mu \mathrm{g}$ collagen. Results are expressed as units of ESAF/mg protein in the supernatant, where one unit of ESAF will activate sufficient latent collagenase to degrade $1 \mu \mathrm{g}$ collagen $/ \mathrm{h}$. All assays were performed in duplicate. Linearity for this method is good up to 6 units of ESAF $/ \mathrm{ml}$. Higher values were diluted accordingly.

\section{Comparison of ESAF from decidua and HUAF with ESAF from other sources}

A single sample ( $5 \mathrm{ml}$ ) of ESAF extract from HUAF was purified by HPLC and its elution profile was compared with that from bovine and human pineal glands, synovial fluid and serum.

\section{Angiogenic activity in vivo of ESAF from decidua and HUAF}

ESAF purified by HPLC was applied to a chick yolk sac membrane to confirm angiogenic activity.

\section{Results}

Both bovine and human decidua contained concentrations of ESAF comparable to those in other highly vascular tissues, such as brain and kidney (Fig. 1), but contained considerably less than the pineal gland (Taylor et al., 1988). Extraction of ESAF from HUAF increased its specific activity significantly, giving $1.6 \pm 0.28$ units of ESAF/mg protein compared with $0.2 \pm 0.04$ units of $\mathrm{ESAF} / \mathrm{mg}$ protein. ESAF extracted from HUAF was identical to ESAF isolated from other sources 
in terms of its behaviour on HPLC. After purification, the active fraction eluted at 8 min from the final reverse-phase HPLC column, which is a time identical to that of ESAF purified from all other tissue sources (Fig. 2). ESAF from decidua and HUAF gave a typical spoke-wheel response on the chick yolk sac membrane (not shown) confirming its property as an angiogenic factor.

(a)

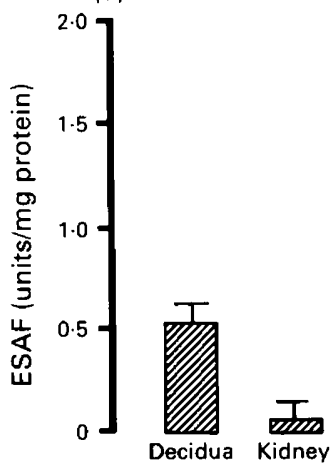

(b)

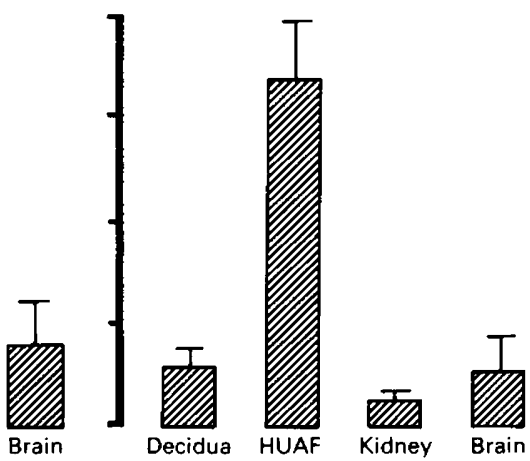

Fig. 1. Concentrations of endothelial-cell-stimulating angiogenesis factor (ESAF) in (a) bovine decidua, kidney and brain (average of three separate animal assays) and (b) pooled human samples of decidua, kidney and brain and of extracts of human uterine angiogenesis factor (HUAF; average of triplicate assays). Bars indicate SEM.

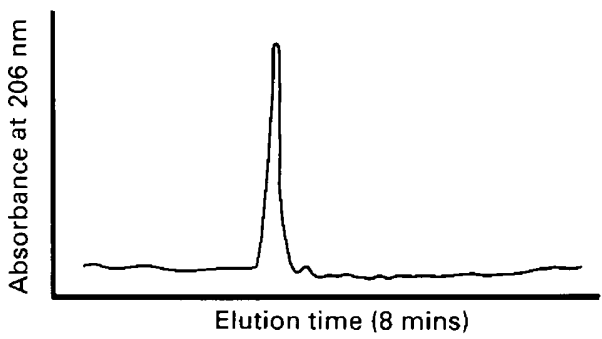

Fig. 2. Absorbance profile of endothelial-cell-stimulating angiogenesis factor (ESAF) from human uterine angiogenic factor with final solvent system on high pressure liquid chromatography. This profile is identical to that of ESAF from all other tissue sources tested.
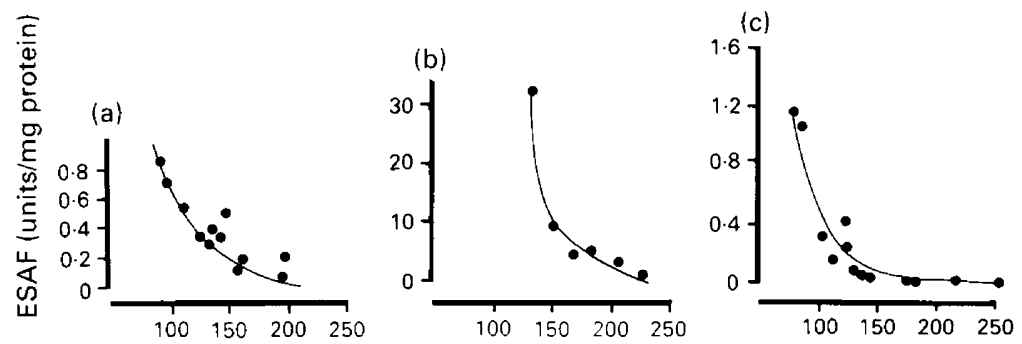

Gestational age (days)

Fig. 3. Concentrations of endothelial-cell-stimulating angiogenesis factor (ESAF) in developing bovine tissues in relation to gestational age of the fetus: (a) brain, (b) growth plate and (c) diaphysis.

Extraction of ESAF from fetal bovine tissues showed a decline in concentration with increasing gestational age in the brain, diaphysis and epiphyseal growth plate (Fig. 3). 


\section{Discussion}

Fibroblast growth factor is a major active component of HUAF (Lindenbaum et al., 1989). We now show that ESAF is another major component of HUAF, suggesting that these two angiogenic molecules are co-distributing. In decidua a dramatic increase in the density and number of blood vessels occurs during the first trimester. The co-occurrence of ESAF and FGFs might be expected to direct the mitogenic activity of these latter factors towards the stimulation of blood vessel growth, as synergism has been reported between ESAF and basic FGF in the stimulation of microvessel endothelial cell growth in vitro (Odedra \& Weiss, 1987); the same synergistic effect has been observed in vivo on the chick yolk sac membrane (Odedra \& Weiss, 1991). Co-distribution of ESAF and FGF occurs in other situations; the tumour angiogenesis factor described by Folkman et al. (1971) is now known to contain FGFs and ESAF as its active components (Weiss et al., 1979; Klagsbrun et al., 1986). Neither ESAF nor FGF alone has as great an activity in vivo as a mixture of the two (Odedra \& Weiss, 1991) and comparable results have been found in vitro using cultured microvessel endothelial cells (Odedra \& Weiss, 1987). Similarly, we have observed that HUAF has a greater activity on the chick yolk sac membrane than either ESAF or FGF alone (J. B. Weiss, C. M. Taylor \& R. Odedra, unpublished observation).

The high concentrations of ESAF detected in first-trimester human and bovine decidua may reflect the intense vascularization that occurs during this period and this is confirmed in the three fetal bovine tissues investigated, in which concentrations of ESAF declined after the first trimester (Fig. 3). ESAF may have a role in changes that occur in the cervix at parturition. Studies by Raynes et al. (1988a) suggest that collagenase activity in the cervix is low and does not increase during pregnancy. This may be due, in part, to the presence of substantial and increasing quantities of TIMP in the cervix (Raynes et al., 1988b) causing most of any collagenase present to be in the form of a TIMP-collagenase complex. Such collagenase cannot be activated by aminophenylmercuric acetate and so is effectively silent in any assay system. That concentrations of collagenase in human cervix and lower uterine segment increase approximately tenfold during labour (Rajabi et al., 1988) suggests either a rapid increase in the synthesis of collagenase at the expense of its inhibitor or the activation of indigenous collagenase complexes. ESAF is the only biological agent shown to be capable of dissociating this complex and releasing active collagenase molecules (McLaughlin et al., 1991). It is therefore possible that ESAF is involved in cervical changes during labour because of its ability to activate complexed collagenase in the extracellular matrix.

\section{References}

Bogart, R. (1959) Improvements of Livestock. Macmillan Press, NY.

Brown, R.A., Taylor, C.M., McLaughlin, B., McFarland, C.D., Weiss, J.B. \& Ali, S.Y. (1987) Identification of an angiogenic procollagenase activator from epiphyseal growth plate cartilage and mineralising chondrocytes in culture. Bone and Mineral 3, 143158.

Burgos, H. (1983) Angiogenic factors from human placenta. European Journal of Clinical Investigation 13, 289-293.

Folkman, J., Merler, E., Abernathy, C. \& Williams, G. (1971) Isolation of a tumour factor responsible for angiogenesis. Journal of Experimental Medicine 133, $275-288$.

Gospodarowicz, D., Cheng, J., Lui, G. M., Lund, D., Crum, R. \& Klagsbrun, M. (1985) Fibroblast growth factor in human placenta. Biochemical and Biophysical Research Communications 128, 554-560.

Klagsbrun, M., Sasse, J., Sullivan, R. \& Smith, J. A. (1986) Human tumour cells synthesize an endothelial cell growth factor that is structurally related to basic FGF. Proceedings of the National Academy of Science (USA) 83, 2448-2452.

Lindenbaum, E.S., Kaufman, T., Beach, D. \& Maroudas, N.G. (1989) Uterine angiogenic factor induces vascularisation of collagen sponges in guinea pigs. Burns 15, 225-229.

Lowry, O.H., Rosenbrough, M.J., Farr, A.L. \& Randall, R.J. (1951) Protein measurement with a folin phenol reagent. Journal of Biological Chemistry 193, 265-275.

McLaughlin, B., Cawston, T. \& Weiss, J.B. (1991) Activation of the matrix metalloproteinase inhibitor complex by a low molecular weight angiogenic factor. Biochimica et Biophysica Acta 1073, 295-298.

Maroudas, N.G., Fuchs, A., Lindenbaum, E.S. (1987) The non-tumour perspective geometry in growth control. In Ocular Circulation and Neovascularisation, Eds D. BenEzra and J. Ryan. J. Martinus Nijhoff, Dordech.

Mercola, M. \& Stiles, C.D. (1988) Growth factor superfamilies and mammalian embryogenesis. Development $102,45 !-461$. 
Odedra, R. \& Weiss, J.B. (1987) A synergistic effect on microvessel endothelial cell proliferation between fibroblast growth factor and ESAF. Biochemical and Biophysical Research Communications 143, 947-953.

Odedra, R. \& Weiss, J.B. (1991) Low molecular weight angiogenic factors. Pharmacology and Therapeutics $49,111-124$.

Rajabi, M.R., Dean, D.D., Beydoun, S.N. \& Woessner, J.F. (1988) Elevated tissue levels of collagenase during dilation of uterine cervix in human parturition. American Journal of Obstetrics Gynaecology 159, 971-976.

Raynes, J.G., Anderson, J.C., Fitzpatrick, R.J. \& Dobson, H. (1988a) Increased collagenase activity is not detectable in cervical softening in the ewe. Collagen and Related Research 8, 46I-469.

Raynes, J.G., Clarke, F.A., Anderson, J.C., Fitzpatrick, R.J. \& Dobson, H. (1988b) Collagenase inhibitor concentration in cultured cervical tissue of sheep is increased in late pregnancy. Journal of Reproduction \& Fertility 83, 893-900.

Taylor, C.M., Weiss, J.B., Kissun, R.D. \& Garner, A. (1986) Effect of oxygen tension on the quantities of procollagenase activating angiogenic factor present in the developing kitten retina. British Journal of Ophthalmology 70, 162-165.

Taylor, C.M., McLaughlin, B., Weiss, J. B. \& Smith, I. (1988) Bovine and human pineal glands contain substantial quantities of endothelial cell stimulating angiogenesis factor. Journal of Neural Transmission $71,79-84$.

Taylor, C.M., Kissun, R.D., Schor, A.M., McLeod, D., Garner, A.\& Weiss, J.B. (1989) Endothelial cell stimulating angiogenesis factor in vitreous from extraretinal neovascularisation. Investigative Ophthalmology and Visual Science 30, 2174-2178.

Weiss, J.B., Brown, R.A., Kumar, S. \& Phillips, P. (1979) An angiogenic factor isolated from tumours: a potent low molecular weight compound. British Journal of Cancer 40, 493-496.

Weiss, J.B., Hill, C.R., Davis, R.J., McLaughlin, B., Sedowofia, K.A. \& Brown, R.A. (1983) Activation of a procollagenase by low molecular weight angiogenesis factor. Bioscience Reports 3, 171-177.

Received 24 January 1991 